\title{
Vase life and rehydration capacity of dry-stored gladiolus flowers at low temperature
}

\section{Lucas Cavalcante da Costa $^{1^{*}}$ Fernanda Ferreira de Araújo $^{2}$ Mirelle Nayana de Sousa Santos ${ }^{2}$ Paula Cristina Carvalho Lima ${ }^{2}$ Ariana Mota Pereira ${ }^{1}$ Fernando Luiz Finger ${ }^{1}$}

'Departamento de Fitotecnia, Universidade Federal de Viçosa (UFV), 36570-900, Viçosa, MG, Brasil. E-mail: costalc@ymail.com. ${ }^{*}$ Corresponding author.

${ }^{2}$ Departamento de Biologia Vegetal, Universidade Federal de Viçosa (UFV), Viçosa, MG, Brasil.

\begin{abstract}
Normally, it is not recommended the conditioning of gladiolus stems in water during storage or transport. Hydration of petals may accelerate flower opening, even at a low temperature, which compromises quality at marketing moment. However, for this species, neither the effect of prolonged dry cold storage nor its behavior when transferred to water at room temperature has been evaluated. The present study aimed to evaluate the vase life and the rehydration capacity of gladiolus flowers (Gladiolus grandiflora Hort.) after dry storage at low temperature. Flower stems of cultivars Blue Frost, Gold Field, Traderhorn, and Jester were dry-stored at a temperature of $5 \pm 1{ }^{\circ} \mathrm{C}$ and relative humidity of $85 \%$ for $12,24,36$, and 48h. Control stems remained always in deionized water. After storage, they were returned to the water at room temperature and evaluated for vase life (adopting the discard criterion when 50\% of the basal flowers displayed loss of color and wilting), fresh weight change (\%), water uptake rate and transpiration rate, as well as relative water content of the petals (\%). In dry cold storage conditions, for up to $36 \mathrm{~h}$, the vase life was not affected although incomplete rehydration of the flowers. Rehydration capacity of the stem is linked to the staggered opening of flowers along the inflorescence. Key words: Gladiolus grandiflora (Hort.), dry storage, cold storage, vase life, relative water content.
\end{abstract}

Vida de vaso e capacidade de reidratação de flores de gladíolo armazenadas a seco em baixa temperatura

RESUMO: Normalmente, não é recomendado o condicionamento de hastes de gladiolo em água durante o armazenamento ou transporte. A hidratação das pétalas acelera a abertura das flores, mesmo em baixa temperatura, o que compromete a qualidade no momento da comercialização. No entanto, para essa espécie, ainda não foi estudado o efeito do armazenamento refrigerado prolongado a seco e nem o seu comportamento quando transferida para a água em temperatura ambiente. O presente estudo teve como objetivo avaliar a vida de vaso e a capacidade de reidratação de hastes florais de gladiolo após armazenamento a seco em baixa temperatura (Gladiolus grandiflora Hort.). As hastes das cultivares Blue Frost, Gold Field, Traderhorn e Jester foram armazenadas a seco em temperatura de $5 \pm 1{ }^{\circ} \mathrm{C}$ e umidade relativa de 85\% por 12, 24, 36 e 48 horas. As hastes controle permaneceram sempre em água deionizada. Após armazenamento, retornaram a água sob condição de temperatura ambiente (22 $\left.\pm 1{ }^{\circ} \mathrm{C}\right)$ e foram avaliadas quanto à vida de vaso (adotando o critério de descarte quando 50\% das flores basais apresentaram perda de coloração e murcha), variação da massa de matéria fresca (\%), taxa de absorção de água e taxa transpiratória, bem como o teor relativo de água das pétalas (\%). Em condições de armazenamento a seco em baixa temperatura, por até 36 horas, a vida de vaso não foi afetada, embora tenha ocorrido reidratação incompleta das flores. A capacidade de reidratação da haste está relacionada com a abertura escalonada das flores ao longo da inflorescência. Palavras-chave: Gladiolus grandiflora (Hort.), armazenamento a seco, armazenamento refrigerado, vida de vaso, teor relativo de água.

\section{INTRODUCTION}

The preservation form of postharvest ornamental quality of cut flowers is specific for each species. In general, producers seek to optimize water relations promoting the maintenance of tissue hydration. Loss of cell turgor, followed by flower senescence during the postharvest life, is the main factor of rejection by consumers (MEMON et al., 2012).

During the transport and commercialization cut flowers are usually not conditioned in water, which may cause permanent wilting, preventing the recovery of tissue hydration when it is returned to the water (VIEIRA et al., 2011). This can be a result of several factors, among which are the blockage and dehydration of xylem vessels, either by embolism or by development of microorganism (VAN DOORN et al., 2002; VIEIRA et al., 2012). Aiming to maintain the flower hydration, temperature control during storage or transport is among the main techniques utilized by producers, as it reduces the use of carbohydrates by respiration, slows the water loss, inhibits the development of pathogens, and reduces the production and action of ethylene (VIEIRA et al., 2011).

Optimal storage temperature for cut flowers, in most cases, is based on the temperatures indicated for other species, though it is known that responses can vary even between cultivars (CEVALLOS \& REID, 2001; MAPELI et al., 2011). For instance, low temperatures are not recommended in the storage of 
tropical flowers, as they cause physiological damage (COSTA et al., 2010). In Alpinia sp., Strelitzia sp., and Heliconia sp., the recommended temperature without the development chilling-related injuries is between 10 and $13{ }^{\circ} \mathrm{C}$ (FINGER et al., 2003; JAROENKIT \& PAULL, 2003; COSTA et al., 2010). According to CEVALLOS \& REID (2001), the vase life of cut gillyflowers, narcissuses, irises, chrysanthemums, roses, and tulips is not changed when the plant is conditioned in water or dry, provided that the storage temperature is between 0 and $10{ }^{\circ} \mathrm{C}$.

Storage in water is not recommended for gladiolus stems, even at low temperatures, since the hydration of petals may accelerate flower opening, causing excess maturation, which compromises their quality at marketing (VEILING, 2009). Good results in dry and cold storage depends on the knowledge of the ideal temperature and storage time (MACNISH et al., 2009; AHMAD et al., 2012). According to REID (2004), for gladiolus, the recommended temperature is $5{ }^{\circ} \mathrm{C}$, as it is safe regarding to chilling. However, in gladiolus, no studies have investigated the effect of prolonged dry cold storage or its response when transferred to water at room temperature aiming to rehydrate flowers.

Hydration is practiced to restore the water balance of cut flowers transported and dry-stored to reestablish turgidity (SUZUKI et al., 2001; VIEIRA et al., 2011; SANTOS et al., 2012; AHMAD et al., 2014). Water deficit occurs when the water uptake rate is lower than the flower's transpiration rate. A high transpiration rate coupled with limited absorption, due to the composition of the solution or due to high resistance and low hydraulic conductance of the xylem vessels, are the main factors negatively affecting the maintenance of postharvest quality of cut flowers (VIEIRA et al., 2012; SALEEM et al., 2014; COSTA et al., 2015).

The objective of the present study was to evaluate the vase life and the rehydration capacity of gladiolus flowers after dry storage at low temperature.

\section{MATERIALS AND METHODS}

The experiment was conducted at the Universidade Federal de Viçosa, located in Viçosa-MG, Brazil (Latitude: 2045'14' S, Longitude: 4252'55" W, Altitude: $648 \mathrm{~m}$ ). Stems of Gladiolus grandiflora (Hort.) cultivars Blue Frost, Gold Field, Green Star, and Jester were used. The commercial harvest point of the species was adopted; i.e., flowers were harvested when the flower buds showed the color of the cultivar. After the harvest, stems were placed in containers with water and then taken to the laboratory, where the base of the stem in water was cut and stems were standardized to a length of $70 \mathrm{~cm}$. Afterwards, flower stems were distributed at random across the treatments.

After the standardization, stems were wrapped in Kraft paper and packed in perforated plastic bags. Next, they were dry-stored in a cold room at $5^{\circ} \mathrm{C}$ in the vertical position at a temperature of $5 \pm 1{ }^{\circ} \mathrm{C}$, relative humidity (RH) $85 \%$, for 12,24 , and $48 \mathrm{~h}$. Control stems remained in deionized water at all times. At the end of each period, inflorescences were returned to containers with $100 \mathrm{~mL}$ water maintained at room temperature $\left( \pm 22{ }^{\circ} \mathrm{C}\right)$. After $0,1,2,3,4,5,6,12$, and $24 \mathrm{~h}$ in water, the following variables were evaluated: fresh weight change, water uptake rate, transpiration rate, relative water content, and vase life of inflorescences (number of days between the onset of return to water and the appearance of wilting in at least $50 \%$ of the flowers).

Initial fresh weight was assigned the value of $100 \%$. Fresh weight change was estimated as a percentage in relation to the initial weight of the stems, according to the following formula:

$\mathrm{FWC}=\left(\mathrm{FWS}_{\mathrm{T}} \times 100\right) / \mathrm{IWS}_{\mathrm{T}}$

FWC: fresh weight change, $\%$;

$\mathrm{FWS}_{\mathrm{T}}$ : final fresh weight of stem;

$\mathrm{IWS}_{\mathrm{T}}$ : initial fresh weight of stem.

Water uptake rate was determined according to methodology described by VAN DOORN et al. (2002) and VIEIRA et al. (2012). After storage, stems were placed in individual tubes, initially weighed, containing $100 \mathrm{~mL}$ deionized water. Tubes were weighed daily with and without the stems. To negate the effects of evaporation, the upper extremity of the tubes was coated with four layers of polyvinyl chloride (PVC) film. Water uptake rate of each solution was estimated as the volume of solution absorbed, in $\mathrm{mg} \mathrm{g}^{-1}$ of fresh weight (FW), calculated by the following formula:

$\mathrm{V}=\left(\mathrm{IWS}_{\mathrm{o}}-\mathrm{FWS}_{\mathrm{o}}\right) / \mathrm{FWS}_{\mathrm{T}}$

$\mathrm{V}$ : volume of solution absorbed;

IWS : initial weight of solution;

$\mathrm{FWS}_{\mathrm{o}}$ : final weight of solution; $\mathrm{FWS}_{\mathrm{T}}$ : final fresh weight of stem.

The transpiration rate was estimated, in $\mathrm{mg} \mathrm{g}^{-1} \mathrm{FW}$, by subtracting the stem fresh weight change from the volume of solution consumed, by the formula described below:

$\mathrm{T}=\mathrm{Vc}-\left(\mathrm{FWS}_{\mathrm{T}-} \mathrm{IWS}_{\mathrm{T}}\right)$

$\mathrm{T}$ : transpiration rate

Vc: volume of solution consumed;

$\mathrm{FWS}_{\mathrm{T}}$ : final fresh weight of stem;

$\mathrm{IWS}_{\mathrm{T}}$ : initial fresh weight of stem.

The relative water content (RWC) of the petals was determined according to the method described by CATSKY (1974), with adaptations, at the 
end of the dry storage period and 4, 8, 12, 16, 20, and $24 \mathrm{~h}$ after they were returned to water. Petals remained in the moistened foam until complete saturation for $24 \mathrm{~h}$; next, the material was weighed again to obtain the turgid weight. After the turgid weight was obtained, petals were dried in an oven at $70^{\circ} \mathrm{C}$ for $72 \mathrm{~h}$ to obtain the constant dry weight. The relative water content was calculated according to the following equation:

RWC $=100$ (FW-DW)/(TW-DW)

RWC: relative water content, expressed in \%;

FW, DW, and TW: fresh weight, dry weight, and turgid weight, respectively.

Analysis of variance (Anova) with 1\% significance, Tukey's test, and a descriptive statistics based on the mean values and standard error were performed.

\section{RESULTS AND DISCUSSION}

There was no significant interaction between cultivars and dry storage time, or any isolated effect of cultivar, on any variable. There was an isolated effect of treatments on fresh weight change after $24 \mathrm{~h}$ of rehydration and on vase life. Thus, the study continued using only the effect of treatments.

Gladiolus flower vase life was reduced in the treatment with $48 \mathrm{~h}$ (Figure 1). The vase life of the inflorescences ranged from three to five days, totaling a difference of approximately $26 \%$ between control and the worst treatment (48h). Stems dry-stored for $36 \mathrm{~h}$ at $5^{\circ} \mathrm{C}$ showed little variation in vase life. It was thus demonstrated that vase life implies quality of gladiolus inflorescences, as it allows a longer time under marketing conditions, especially during transport. Contrasting the results found by SANTOS et al. (2012) with Epidendrum ibaguense, in which, irrespective of the dry storage time, there was a reduction in vase life of the inflorescences. In their study, dry storage of stems for only $12 \mathrm{~h}$ was sufficient to reduce vase life. VIEIRA et al. (2011); however, reported that cold and dry storage for two days retarded the senescence of cut inflorescences of snapdragon (Antirrhinum majus) and prolonged the marketable period, provided that it was associated with the use of preservative solutions such as 8 -HQC + sucrose + citric acid post-storage. In an experiment with dry storage and with water in several species, AHMAD et al. (2012) observed that cut roses of cultivar Angelique had a longer vase life when dry-stored for two weeks than those stored in water for the same period.

As shown in figure 2A, there was a decrease in stem fresh weight during storage when compared with control. This reduction was proportional to the storage time. All flower stems gained weight in the first $12 \mathrm{~h}$, which remained constant for $24 \mathrm{~h}$. Differently, plants from control treatments increased in weight in the first $6 \mathrm{~h}$, with little variation after the $12 \mathrm{~h}$, maintaining fresh weight below that obtained in the treatments with 12, 24, and $36 \mathrm{~h}$.

The greater fresh weight accumulation capacity after the treatments of 12,24 , and $36 \mathrm{~h}$ in relation to control may be related to the flower opening induced by the presence of water in control, which increases the exposure of tissues and consequently transpiration. Another factor that may be related to the divergence among treatments is the difference between room temperature $\left(22^{\circ} \mathrm{C}\right)$ and storage temperature $\left(5^{\circ} \mathrm{C}\right)$, which favors the concentration of humidity on the tissue surface.

The only time at which rehydration was not established was $48 \mathrm{~h}$ of dry storage. Greater damage was reported in the flowers under water stress prolonged for more than $36 \mathrm{~h}$. A similar result was observed by VAN MEETEREN et al. (2006) in chrysanthemum, with no recovery of turgescence of flowers, in which the dry storage of stems at $20^{\circ} \mathrm{C}$ for one hour led to a reduction in fresh weight in the $23 \mathrm{~h}$ during which stems remained in water. In a study conducted by AHMAD et al. (2012), stems of roses stored in water lost more weight during vase life than those kept in dry storage.

Water uptake rate in the first hour was higher in control, compared with the other treatments. In dry-stored stems, the water uptake rate in the first hour decreased as the storage time was decreased (Figure 2B). After five hours of rehydration, there was a dramatic increase in water uptake rate in all treatments, including control. This increase coincides with the period when the basal flower from the stem start to open and with the peak of transpiration, as can be seen in figure $2 \mathrm{C}$. This fact demonstrated that the room temperature and the induction of staggered opening of flowers in the first hours amplified the water uptake rate. In the dry-stored stems, the water uptake rate had a similar behavior to that shown by fresh weight change (Figure 2A), in which the rate was directly proportional to the duration of water stress. This, in turn, might have generated a greater water uptake potential brought about by tissue dehydration.

Control and flowers stored for $12 \mathrm{~h}$ revealed a similar response in water uptake rate and in transpiration rate after $12 \mathrm{~h}$ of rehydration, whereas in the other treatments there was a decrease in both variables. This decline demonstrates that the tissue was not able to rehydrate possibly due to irreversible damage caused by lack of cell hydration. In an experiment with Epidendrum ibaguense, SANTOS et al. (2012) reported that after $24 \mathrm{~h}$ of rehydration, the 


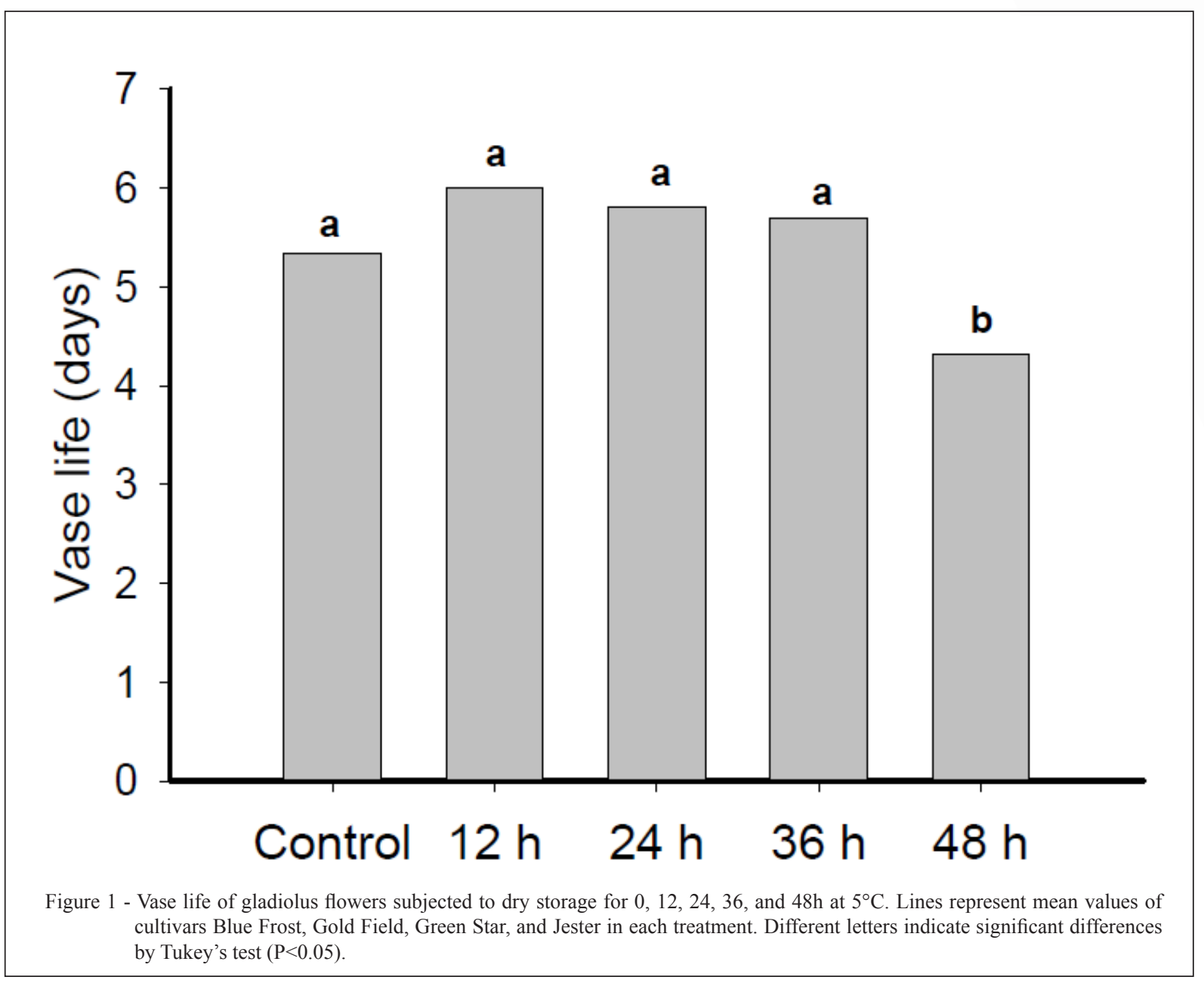

transpiration rate surpassed the water uptake rate in all treatments. Flowers wilted in the period between 24 and $48 \mathrm{~h}$ and after $96 \mathrm{~h}$ in water. Inflorescences of Epidendrum ibaguense did not demonstrate high sensitivity to water stress after harvest, and did not require additional treatments with cutting of the stem base (FINGER et al., 2008).

The RWC of the petals differed as a function of storage time and rehydration utilized (Figure 2D). Stems dry-stored for 12 and 24h, together with control, did not show losses in content after storage, but rather an increase, differently from those under water stress for 36 and $48 \mathrm{~h}$. This response can be explained by the reduced temperature in the storage chamber in comparison with the field. Coupled with the high $\mathrm{RH}$ of the chamber $(85 \%)$, this reduction might have caused a concentration of the water content in the flower, especially on the petal surface, which contributed as a barrier against water loss. However, as this storage time was extended (36 and $48 \mathrm{~h}$ ), this loss became sharper, decreasing by 87 and $82 \%$, respectively.

The relative water content of the petals increased up to the twelve hours of rehydration, regardless of the dry storage time. In flowers under dry storage for 36 and $48 \mathrm{~h}$, the relative water content was kept low throughout the rehydration period. Inflorescences that remained for 12 or $24 \mathrm{~h}$, when subjected to rehydration, reached values near $130 \%$ in relation to the initial RWC of the stems $(100 \%)$. A higher relative water content was observed in the flowers subjected to $12 \mathrm{~h}$ of dry storage, compared with the other treatments and also with control. In control stems, immediate hydration caused an increase in the water content of petals in the first $4 \mathrm{~h}$, followed by a stabilization period, with a decrease after $12 \mathrm{~h}$ in water. Only the stems with 12 and $24 \mathrm{~h}$ of storage had full and superior recovery of the water content in the petals, surpassing the level achieved by control after $12 \mathrm{~h}$ in water. In the stems 


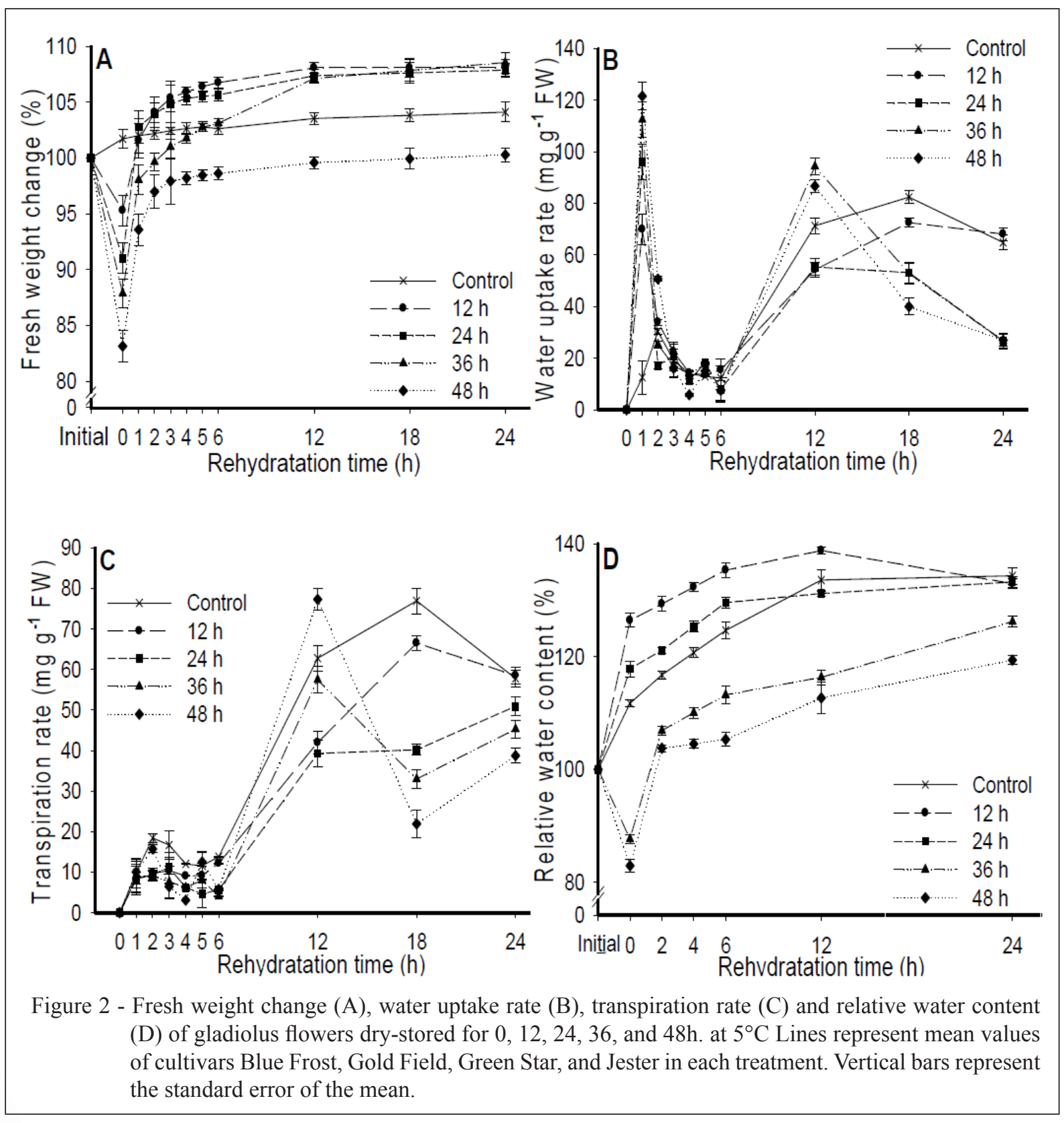

dry-stored for 36 and $48 \mathrm{~h}$, petal rehydration was partial, lower than that of control flowers, even after $24 \mathrm{~h}$ of rehydration.

SANTOS et al. (2102) found that dry storage reduced the water content of petals of Epidendrum ibaguense, and, likewise, the decline was proportional to the duration of water stress. However, only the stems with $12 \mathrm{~h}$ of stress had full recovery of petal water content after 24h. VIEIRA et al. (2011) observed that, regardless of storage time, after the same period, the water content of snapdragon was lower than stems were placed in deionized water, with a reduction of 71 and $70 \%$ from zero time to 55 and $56 \%$ when stored for two and four days, respectively.

\section{CONCLUSION}

Vase life of gladiolus flowers is not affected by the partial recuperation of the relative water content, when dry-stored for up to $36 \mathrm{~h}$ at $5^{\circ} \mathrm{C}$. Furthermore, the staggered opening of flowers is a major event that contributes with rehydration capacity of gladiolus stems. 


\section{ACKNOWLEDGMENTS}

The authors are grateful to Fundação de Amparo à Pesquisa do Estado de Minas Gerais (FAPEMIG) and Conselho Nacional de Desenvolvimento Científico e Tecnológico (CNPq) for financial support.

\section{REFERENCES}

AHMAD, I. et al. Optimal postharvest handling protocols for cut 'Line Dance' and 'Tap Dance' Eremurus inflorescences. Scientiae Horticulturae, v.179, p.212-220, 2014. Available from: <http:// www.sciencedirect.com/science/article/pii/S0304423814005093> Accessed: July 15, 2015. doi: 10.1016/j.scienta.2014.09.031.

AHMAD, I. et al. Dry storage effects on postharvest performance of selected cut flowers. HortTechnology, v.22, p.463-469, 2012. Available from: <http://horttech.ashspublications.org/content/22/4/463.full.pdf>. Accessed: Jan. 12, 2015.

CÁTSKY, J. Water content. In: SLAVIK, B. Methods of studying plant water relations. Berlin: Springer-Verlag, 1974. p.121-131.

CEVALLOS, J.C.; REID, M.S. Effect of dry and wet storage at different temperatures on vase life of cut flowers. Hort Technology, v.11, p.199-202, 2001. Available from: <http:/horttech.ashspublications. org/content/11/2/199.full.pdf>. Accessed: Nov. 23, 2014.

COSTA, A.S. et al. Characterization of symptoms of senescence and chilling injury on inflorescences of Heliconia bihai (L.) cv. Lobster Claw and cv. Halloween. Postharvest Biology and Technology, v.59, p.1-7, 2010. Available from: <http://www.sciencedirect.com/ science/article/pii/S0925521410001894>. Accessed: Jun. 25, 2015. doi: 1016/j.postharvbio.2010.08.015.

COSTA, L.C. et al. Postharvest longevity of Heliconia wagneriana. Acta Horticulturae, v.1060, p.93-199, 2015. Available from: $<$ http:// www.actahort.org/books/1060/1060_28.htm>.Accessed: Feb. 10, 2015.

FINGER, F.L. et al. Vase life of bird-of-paradise flowers influenced by "pulsing" and term of cold storage. Acta Horticulturae, v.628, n.1, p.863-867, 2003. Available from: <http://www.actahort.org/ books/628/628_110.htm>. Accessed: Mar. 10, 2015.

FINGER, F.L. etal.Longevity of Epidendrum ibaguense flowers as affected by pre-loading treatments and vase solution. Journal of Horticultural Science and Biotechnology, v.83, p.144-147, 2008. Available from: $<\mathrm{http}: /$ www.tandfonline.com/doi/abs/10.1080/14620316.2008.11512361> .Accessed: Jan. 20, 2015. doi: 10.1080/14620316.2008.11512361.

JAROENKIT, T.; PAULL, R.E. Postharvest handling of heliconia, red ginger and bird-of-paradise. HortTechnology, v.13, n.2, p.259266, 2003. Available from: <http://horttech.ashspublications.org/ content/13/2/259.full.pdf>. Accessed: Mar. 10, 2015.

MACNISH, A.J. et al. An alternative postharvest handling strategy for cut flowers - Dry handling after harvest. Acta Horticulturae, v.847, p.215221, 2009. Available from: <http://www.actahort.org/books/847/847_27. htm>. Accessed: Jan. 28, 2015.
MAPELI, A.M. et al. Influence of storage temperature on Epidendrum ibaguense flowers. Acta Scientiarum. Agronomy, v.33, n.1, p.111115, 2011. Available from: $<$ http://www.scielo.br/scielo.php?script=sci arttext\&pid=S1807-86212011000100016>. Accessed: Jan. 20, $201 \overline{5}$. doi: 10.4025/actasciagron.v33i1.6365.

MEMON, N. et al. Membrane stability and postharvest keeping quality of cut Gladiolus flower spikes. Journal of Agricultural Technology, v.8, n.6, p.2065-2076, 2012. Available from: <http://www.ijat-aatsea. com/pdf/v8_n6_12_November/18_IJAT_2012_8(6)_Memon,\%20N_ Plant\%20Science.pdf $>$. Accessed: Feb. 10, 2015.

REID, M.S. Gladiolus. Recommendations for Maintaining Postharvest Quality. 2004. Available from: <http://postharvest. ucdavis.edu/pfornamentals/Gladiolus/>. Accessed: Sept. 29, 2014.

SALEEM, M. et al. Vase water effects on postharvest longevity and water relations of Gladiolus grandiflorus 'White Prosperity'. Pakistan Journal of Agricultural Sciences, v.51, n.1, p.137-141, 2014. Available from: $<$ http://pakjas.com.pk/papers\%5C2252.pdf >. Accessed: Feb. 10, 2015.

SANTOS, J.S. et al. Capacity of rehydration and influence of cut on the recovery of water flow in inflorescences of Epidendrum ibaguense. Revista Brasileira de Horticultura Ornamental, v.18, n.1, p.15-21, 2012. Available from: $<$ http://ornamentalhorticulture.emnuvens.com.br/ rbho/article/viewFile/689/499>. Accessed: Jan. 15, 2015. doi: 10.14295/ rbho.v18i1.689.

SUZUKI, A. et al. Effects of retail hydration on water uptake and quality of "Madame Delbard" roses after long term transport. Acta Horticulturae, v.543, p.251-256, 2001. Available from: $<$ http://www. actahort.org/books/543/543_30.htm>. Accessed: Jan. 28, 2015.

Van DOORN, W.G. et al. Alkylethoxylate surfactants for rehydration of roses and Bouvardia flowers. Postharvest Biology and Technology, v.24, p.327-333, 2002. Available from: <http://www.sciencedirect. com/science/article/pii/S0925521401001521>. Accessed: Feb. 20, 2015. doi: 10.1016/S0925-5214(01)00152-1.

Van MEETEREN, U. et al. Inhibition of water uptake after dry storage of cut flowers: Role of aspired air and wound-induced processes in Chrysanthemum. Postharvest Biology and Technology, v.41, p.7077, 2006. Available from: <http://www.sciencedirect.com/science/ article/pii/S0925521406000846>. Accessed: Jun. 10, 2015. doi: 10.1016/j.postharvbio.2006.03.005.

VEILING HOLAMABRA - FLORES E PLANTAS ORNAMENTAIS. Gladíolo. In: . Manual de classificação. 2009. Available from: $<$ http://www.veiling.com.br/uploads/padrao_ qualidade/criterios/gladiolo-fc.pdf>. Accessed: Sept. 28, 2014.

VIEIRA, L.M. et al. Vascular occlusion and water relations in cut snapdragon flowers. Acta Horticulturae, v.937, p.179-184, 2012. Available from: $<$ http:// www.actahort.org/books/937/937 21.htm>. Accessed: Oct. 22, 2014.

VIEIRA, L.M. et al. Water uptake by snapdragon inflorescences cuts after cold dry storage. Ciência Rural, v.41, n.3, p.418-423, 2011. Available from: $<$ http://www.scielo.br/scielo.php?script=sci arttext \&pid $=$ S0103-84782011000300009 $>$. Accessed: Jan. 20, 2014. doi: $10.1590 / \mathrm{S} 0103-84782011000300009$. 